\title{
KOMPILASI HUKUM ISLAM (Suatu Formalisasi Syari'at Islam di Indonesia)
}

\author{
Taufiqurrahman \\ (Jurusan Syari'ah STAIN Pamekasan, jln. Pahlawan KM. 04 Pamekasan, email: \\ wargamadura@yahoo.com)
}

\begin{abstract}
Abstrak
Terbit dan berlakunya Kompilasi Hukum Islam (KHI) sejak tahun 1991 di Indonesia merupakan indikasi nyata bahwa hukum Islam telah diakui keberadaannya sebagai hukum positif di negeri ini. Kondisi itu sesungguhnya berarti bahwa secara formal sebagian syari'at (hukum) Islam diakomodasi keberlakuannya. Dalam konteks itulah dapat dinyatakan bahwa formalisasi Syari'at Islam di Indonesia dapat terwujud dan sama sekali bukanlah sesuatu yang terlarang untuk terus diupayakan, apalagi untuk sekedar diwacanakan. Yang terpenting justru terletak pada terwujudnya kesadaran sekaligus dukungan dari tiap individu muslim untuk memahami bahwa ajaran Islam merupakan ajaran tentang hidup dan kehidupan manusia, dan bukan hanya sebatas bidang Perkawinan, Kewarisan, dan Perwakafan, sebagaimana yang ditampakkan pada wilayah/muatan KHI.
\end{abstract}

\begin{abstract}
Since 1991, Indonesia has been launched and legally effective the Islamic Law Compilation (KHI). It indicates that Islamic law has already accepted as positive law in Indonesia. The condition means that Islamic law is formally acknowledged and accommodated. This is to declare that the formalization of Islamic law (syari'at) is able to realize and it is not prohibited to discuss it as a discourse. The most important aspect is that how to apprehend as well as to support its comprehension to every Muslim. Islamic teaching is tenet of human life and not only including matters of marriage, inheritance, and charity as has been imaged in KHI contents.
\end{abstract}


Taufiqurrahman

\section{Kata-kata Kunci}

KHI, Hukum Islam, Syari'at Islam.

\section{Pendahuluan}

Kompilasi hukum Islam (KHI) dapat didefinisikan secara etimologis sebagai naskah, kitab, atau buku yang berisi himpunan pendapat hukum fuqahấ (baca: hasil ijtihâd, istinbâth al-hhukm) tentang ajaran Islam yang dikutip dari berbagai kitab fikih dan digunakan sebagai rujukan dalam memecahkan atau menghadirkan solusi tentang persoalan-persoalan hukum. Di Indonesia, KHI dirangkum oleh para pakar hukum Islam dan digunakan, terutama, sebagai rujukan oleh hakim-hakim Pengadilan Agama dalam memutus atau menetapkan perkara yang diajukan kepadanya. Oleh karena itu, KHI dapat disebut sebagai salah satu referensi-solutif atas perkara yang menjadi kewenangan Pengadilan Agama.

Jika upaya mengompilasi hukum Islam, sebagai bagian dari formalisasi hukum (syari'at) tidak dilakukan maka menurut Abdurrahman akan berakibat antara lain pada: (1) ketidakbakuan atau ketidakseragaman tentang ketentuan-ketentuan hukum (syari'at) Islam yang disepakati sebagai bagian dari kepastian hukum; (2) ketidakjelasan tentang bagaimana cara penerapan syari'at Islam; (3) ketidakmampuan para hakim untuk menggunakan perangkat dan alat-alat hukum formil yang telah diamanatkan dan disediakan oleh UUD 1945 maupun peraturan perundang-undangan lainnya. ${ }^{1}$ Kondisi demikian akan berdampak sangat serius dalam bentuk ketiadaan pedoman bagi para hakim Pengadilan Agama untuk memutus dan/atau menetapkan perkara, sebagaimana yang pernah dialami sebelumnya. Pada saat itu, para hakim secara bebas merujuk kepada berbagai pendapat fuqahâ' dari kitab-kitab klasik sehingga sering terjadi satu perkara diputus secara berbeda, dan bahkan kerapkali bertentangan antara satu hakim dengan hakim lainnya maupun di antara peradilan-peradilan agama.

Setelah melalui proses yang sangat panjang, pada 10 Juni 1991 diterbitkan Instruksi Presiden RI Nomor 1 Tahun 1991 tentang

1 Abdurrahman, Kompilasi Hukum Islam di Indonesia (Jakarta: Akademika Pressindo, 1992), hlm. 24. 
pemberlakuan dan penyebarluasan Kompilasi Hukum Islam. Materi KHI yang telah disahkan oleh Presiden RI itu terdiri atas tiga buku, yaitu Buku I tentang Hukum Perkawinan, Buku II tentang Hukum Kewarisan, dan Buku III tentang Hukum Perwakafan. ${ }^{2}$ Dengan diterbitkan KHI sebagai buku rujukan hukum Islam bagi institusi pengadilan Agama khusunya, solusi tentang persoalan syari'at/hukum Islam itu menemukan rujukan yang baku dan kokoh secara legal formal, sekurang-kurangnya berkaitan dengan tiga hukum perdata, yaitu tentang perkawinan, kewarisan, dan perwakafan.

Berkaitan dengan diterbitkan KHI sebagai hukum Islam material atau sebagai hukum positif-terapan, artikel ini disusun untuk membahas tentang KHI dalam hubungannya dengan persoalan formalisasi syari'at Islam. Jika ada sebagian orang yang masih dan selalu ingin mempertanyakan, apakah kompilasi hukum Islam merupakan formalisasi syari'at Islam? Jawabannya tentu saja ya! Meskipun begitu, secara legal-formal, sebenarnya pertanyaan itu merupakan lontaran keragu-raguan yang sangat aneh karena kalau berbicara tentang syari'at Islam-dalam pengertian Islamic Law atau syari'at Islam - maka yang diperbincangkan adalah persoalan hukum formal. Dalam istilah lain, pokok pembicaraannya bukan lagi normanorma moralitas atau idea tentang hukum yang batasannya mungkin tidak bertepi.

Jika ditinjau dari segi kehidupan praktis, mengingat derajat (level) hakim Pengadilan Agama rata-rata bukan merupakan mujtahid, maka KHI memang benar-benar diperlukan untuk menciptakan keseragaman keputusan (putusan dan/atau penetapan) hukum syar'iy. Sebelum dijadikan hukum positif boleh saja terjadi perbedaan (baca: keberagaman) hasil-hasil ijtihâd di antara individu hakim maupun antarpengadilan agama. Namun setelah menjadi hukum positif tentu diperlukan keseragaman dan kepastian hukum dalam bentuk aturan yang baku sehingga tidak menimbulkan penafsiran yang kemudian menghasilkan produk hukum yang berbeda-beda untuk satu jenis masalah/perkara serupa.

2 Ibid., hlm. 106. Baca juga: Ensiklopedi Hukum Islam (Jakarta: Intermasa, 1999), hlm. 971-972. 
Persoalan itu sempat dikomentari oleh penulis Ensiklopedi Hukum Islam bahwa dengan diberlakukan Kompilasi Hukum Islam, sebagai pedoman bagi para hakim Pengadilan Agama dalam menyelesaikan perkara-perkara, maka kesatuan, kepaduan, keselarasan, dan kepastian hukum Islam untuk persoalan hukum mu'âmalah (perdata) bagi umat Muslim Indonesia telah berhasil diwujudkan oleh fuqaha' Indonesia. ${ }^{3}$ Daud Ali, seorang pakar Hukum Islam, juga berkomentar positif tentang eksistensi Kompilasi Hukum Islam. Menurutnya, dengan diterbitkan KHI itu, mudah-mudahan, citra hukum Islam di Indonesia menjadi semakin baik, sebagai pedoman baku (standardized) yang mampu ditegakkan oleh aparatur Peradilan Agama--unsur pelaksana kekuasaan kehakiman dalam sistem peradilan nasional. ${ }^{4}$

\section{Posisi Syari'at Islam}

Secara lughawy, syari'at berarti jalan atau cara menuju sumber air atau sumber kehidupan. Di kalangan ahli hukum Islam, syari'at dimaknakan menurut pengertian umum dan khusus. Dalam pengertian umum, syari'at berarti keseluruhan perangkat (tools, alat bantu) kehidupan yang dibutuhkan dalam komunitas kaum muslimi, termasuk di dalamnya pengetahuan tentang aspek-aspek ketuhanan, yang dalam hal ini biasa disebut sebagai figh al-kabîr. Sedangkan dalam pengertian khusus, syari'at berarti ketentuan hukum yang dihasilkan dari pemahaman seorang muslim yang memenuhi syaratsyarat tertentu tentang al-Quran dan al-Sunnah dengan menggunakan metode tertentu (ushîl al-figh, istinbâth al-ḩukm fî alfigh). ${ }^{5}$

Ahmad al-Hushari mendefinisikan syari'at sebagai kumpulan kaidah-kaidah dan hukum-hukum yang disyari'atkan Allah bagi hamba-Nya melalui lisan para Rasul-Nya untuk mengatur hubungan hamba (makhlîq) dengan Allah (khâliq) serta hubungan hamba dengan sesama mereka dalam berbagai aspek kehidupan yang bermacammacam baik dalam urusan sosial, ekonomik, politik, hubungan warga

3 Ibid., hlm, 972.

4 Daud Ali, "Hukum Islam: Peradilan Agama dan Masalahnya", dalam Hukum Islam di Indonesia: Pemikiran dan Praktik, ed. Daud Ali (Jakarta: Rajawali Press 1994), hlm. 87. 5 Juhaya S. Praja, "Pengantar", dalam Hukum Islam di Indonesia: Pemikiran dan Praktik, ed. Daud Ali (Jakarta: Rajawali Press, 1994), hlm. v-vi. 
bangsa dan antarnegara, maupun masalah akhlak, perilaku individu manusia. ${ }^{6}$

Dalam konteks praksis sosial pelaksanaan syari'at Islam, Indonesia memiliki landasan historis dan juridis yang sangat kuat. Sejumlah landasan pemberlakuan syari'at Islam di Indonesia antara lain Pasal 29 Ayat (2) UUD 1945 yaitu negara menjamin kemerdekaan tiap-tiap penduduk untuk memeluk agamanya masing-masing dan untuk beribadat menurut agama dan kepercayaannya itu. ${ }^{7}$ Hazairin, pakar hukum adat dan hukum Islam dari Unversitas Indonesia, berpendapat bahwa istilah beribadat menunjukkan pemahaman sebagai kelanjutan dari jaminan negara bagi tiap-tiap penduduk untuk memeluk agama sebagaimana disebutkan dalam Pasal 29 Ayat (2) itu. Pasal itu memuat pengertian tentang kebebasan dalam menjalankan syari'at (hukum) agama. Oleh karena itu dapat dinyatakan bahwa negara berkewajiban menjalankan syari'at agama Islam sebagai hukum positif bagi umat Muslim, syari'at kristen untuk umat Kristiani, syari'at Hindu untuk umat Hindu, dan seterusnya sesuai dengan syari'at agama yang dianut oleh masing-masing individu warga bangsa Indonesia. Karena tiap agama memiliki syari'at maka diberlakukan syari'at agama tersebut untuk masingmasing penganutnya. 8

Secara lughawy, lafazh ibadat berarti pengabdian, penyembahan, ketaatan, kepasrahan, dan doa. ${ }^{9}$ Yusuf Qardawi mendefinisikan ibadat sebagai sebutan bagi semua perbuatan atau perilaku manusia yang membuat Allah senang dan ridlâ, baik dalam berbentuk ucapan atau perbuatan maupun bersifat lahir atau batin. Menurut ulama mazhab Syâfi'î, ibadat ialah perbuatan yang dibebankan oleh Allah swt kepada hamba-hamba-Nya yang selamanya sesuai dengan fitrah yang bersangkutan. Ibnu Taymiyah

\footnotetext{
6 Ahmad al-Husyari, al-Siyâsah al-Jazâiyah fi Figh al-'Uqûbah al-Islâmiyah al-Muqârin (Kairo: Maktabah al-Siyâsi, 1993), hlm. 10.

7 Undang-Undang Dasar Negara Republik Indonesia Tahun 1945 Beserta penjelasannya (Jakarta: Sekretariat Negara, 2003), hlm. 15.

8 Hazairin, Demokrasi Pancasila (Bandung: Citra Aditya bakti, 1993), hlm. 75. Lihat juga: Rifyal Ka'bah, Hukum Islam di Indonesia (Disertasi Universitas YARSI, Jakarta, 1999), hlm. 77-78.

9 Hasan Alwi, et al, Kamus Besar Bahasa Indonesia (Jakarta: Balai Pustaka, 2003), hlm. 415.
} 
mendefinisikan ibadat sebagai ketaatan, kepasrahan, dan ketundukan makhluk kepada Yang Maha Sempurna. Di dalamnya terdapat unsur kecintaan kepada Dzat yang disembah sehingga ketundukan, kepasrahan, dan ketaatan itu haruslah didasarkan atas kecintaan kepada Dzat Yang Disembah. Berdasarkan penjelasan Ibnu Taymiyah itu, Yusuf Qardlawi kemudian menyatakan bahwa segenap aspek kehidupan manusia dapat bernilai ibadat. Seperti makan, minum, bergaul dalam sistem sosial kemasyarakatan, menjenguk orang sakit, takziyah, silaturrahim, dan sejenisnya. ${ }^{10}$

Dalam Dekrit Presiden 5 Juli 1959 dinyatakan oleh Presiden RI waktu itu bahwa kami berkeyakinan bahwa Piagam Jakarta menjiwai Undang-Undang Dasar 1945 sebagai suatu rangkaian kesatuan dengan konstitusi tersebut. Menurut Prof. Notonagoro, guru besar Universitas Gadjah Mada dan pakar sosial Pancasila, dalam Piagam Jakarta arti kata menjiwai pada Dekrit Presiden 5 Juli 1959 itu, dapat dipahami sebagai berikut:

"bahwa Piagam Jakarta itu menjiwai UUD 1945, khusunya dalam pembukaannya dan pasal 29, pasal mana ia harus menjadi dasar bagi praksis kehidupan hukum di bidang keagamaan ... dengan demikian perkataan ketuhanan dalam pembukaan UUD 1945 dapat diberi pengembangan arti, yaitu Ketuhanan dengan kewajiban bagi umat Islam menjalankan syari'atnya sehingga atas dasar itu pula dapat diciptakan perundang-undangan"..."atau peraturan pemerintah lainnya"..."bagi pemeluk agama Islam, yang dapat disesuaikan"..."(atau yang) tidak bertentangan dengan hukum/syari'at Islam, dan dengan tidak mengurangi ketepatan pemaknaan maupun penafsiran istilah yang termaktub dalam Pasal 29 UUD 1945 bagi pemeluk agama lain."11

Landasan konstitusional pemberlakuan syari'at Islam di Indonesia sebenarnya cukup kuat - apalagi jika "tujuh kata" yang hilang dari Piagam Jakarta dikembalikan lagi dalam konstitusi RI. Akan tetapi, menurut Daud Ali, di dalam negara yang yang

10 Tim Penyusun Ensiklopedi Hukum Islam, Ensiklopedi Hukum Islam (Jakarta: Intermasa, 1999), hlm. 592.

${ }_{11}$ Notonagoro, Pancasila Secara Ilmiah Populer (Bandung: Pustaka Amani, 1971), hlm 16; Lihat Juga: Endang Saifuddin Anshari, Piagam Jakarta 22 Juni 1945 (Bandung: Jenmar, 1997), hlm. 132. 
berdasarkan hukum, hukum itu berlaku kalau ia didukung oleh tiga pilar utama, yaitu (1) lembaga atau penegak hukum yang dapat diandalkan dalam menjalankan misi hukum dan keadilan, (2) terdapat peraturan hukum yang baku dan jelas, dan (3) kesadaran hukum warga masyarakat. Tiga pilar itulah yang seyogyanya diperjuangkan bersama secara simultan oleh para aktivis dan praktisi penegak syari'at Islam. Jika salah satunya timpang, lembek, atau lemah maka pelaksanaan syari'at Islam akan berjalan tidak mulus melainkan penuh rintangan dan hambatan. ${ }^{12}$

\section{Syari'at Islam: Musuh kolonial}

Sejak dunia Islam jatuh ke dalam cengkraman kaum penjajah (kolonial) Barat, upaya untuk menghapuskan syari'at Islam secara sistematis gencar dilakukan. Untungnya, dalam kenyataan syari'at Islam itu begitu "kenyal", karena berakar begitu kuat di tengahtengah masyarakat. Upaya-upaya lain pun untuk terus memadamkan syari'at Islam terus-menerus dilakukan oleh kaum kolonial itu dengan sangat hati-hati. Daud Ali mencatat bahwa dalam Statuta Batavia tahun 1642 disebutkan jika terjadi sengketa kewarisan antara orang-orang pribumi yang beragama Islam harus diselesaikan dengan mempergunakan syari'at Islam, yakni hukum yang diakui, ditaati, dan dijalankan oleh rakyat dalam kehidupan mereka sehari-hari. Selama tiga abad kekuasaan VOC (tahun 1602-1800), kedudukan hukum Islam ternyata tetap kokoh seperti semula, yaitu berlaku dan berkembang di kalangan umat Muslim Indonesia. ${ }^{13}$

Ketika pemerintah kolonial Belanda mulai meraih kekuasaan di Indonesia pada permulaan abad ke-19, sikap mereka terhadap hukum Islam mulai berubah. Perubahan itu dilakukan secara perlahan namun sistemik dan sistematis. Ketika hukum Indonesia hendak ditata dan diubah menurut pola hukum Belanda, Mr. Scolten van Oud Harlem, Ketua Mahkamah Agung Belanda, menasihati pemerintahnya agar melakukannya secara hati-hati untuk mencegah perlawanan dari umat Muslim. Karena hukum anak negeri dan hukum Islam dilanggar, haruslah diikhtiarkan sedapat-dapatnya agar orang-orang pribumi yang beragama Islam dapat tetap diberlakukan

\footnotetext{
12 Ali, Hukum Islam, hlm. 89.

13 Ibid., hlm. 91.
} 
sesuai dengan kondisi lingkungan hukum agama dan adat istiadat mereka. Tahun 1882 penjajah kolonial Belanda membentuk Pengadilan Agama dengan nama yang salah, yakni Priesterraad atau Pengadilan Pendeta di setiap Pengadilan Negeri atau Landraad di Jawa dan Madura, dengan wewenang mengadili perkara-perkara (perdata) yang terjadi di kalangan umat Muslim, menurut hukum Islam.

Dalam hubungan ini perlu dikemukakan bahwa sepanjang abad ke-19 dianut pendapat di kalangan ilmuwan dan pemerintah Belanda bahwa di Indonesia diberlakukan hukum Islam bagi umat Muslim. Pendapat ini antara lain dikemukakan oleh Solomon Keyzer (tahun 1823-1868) dan Lodewijk Willem Cristian van den Berg (tahun 1845-1927). Menurut van den Berg, hukum mengikuti aturan dalam ajaran agama yang dianut seseorang. Kalau dia orang Islam maka hukum Islamlah yang berlaku baginya. Menurutnya pula, orang Islam Indonesia telah melakukan resepsi hukum Islam dalam keseluruhannya secara utuh yang kemudian disebut dengan istilah receptio in complexu. Karena itu pula, istilah itu disebut dan dikukuhkan sebagai teori receptio in complexu.

Dalam perkembangannya, teori van den Berg itu kemudian ditolak atau tidak diakui oleh Cristian Snouck Hurgronje. Menurutnya, yang berlaku bagi orang Islam adalah hukum adat, bukan hukum Islam. Ke dalam hukum adat itu memang telah masuk hukum Islam tetapi pengaruh itu baru mempunyai kekuatan hukum kalau sudah diterima oleh hukum adat. Hukum adatlah yang menentukan ada-tidaknya hukum Islam itu. Pendapat Snouck Hurgronje ini kemudian dikembangkan oleh van Vollenhoven dan Ter Haar. Pendapat hukum itu kemudian dikenal dengan istilah teori receptie. Menurut penganut teori ini, hukum Islam bukanlah hukum. Hukum Islam baru diakui sebagai hukum jika telah menjadi hukum adat. Terserahlah kepada kesediaan masyarakat adat atau penduduk setempat untuk menerima dan menmenjadikan hukum Islam yang dianggap bukan hukum itu menjadi hukum adat.

Menurut Haizirin, teori receptie yang diciptakan oleh kekuasaan kolonial Belanda itu merupakan teori Iblis karena jelasjelas menentang iman kaum Muslim. Sebabnya adalah dengan mengikuti teori itu orang Islam diajak untuk tidak mematuhi alQur'an dan al-Sunnah. Selain itu, teori itu juga bertujuan untuk merintangi kemajuan ajaran Islam di Indonesia. Upaya pemerintah 
kolonial untuk menghapus hukum Islam semakin menampakkan hasil setelah wewenang Pengadilan Agama untuk mengadili perkara waris sesuai hukum Islam dicabut pada tahun 1937.14

Menurut penjajah kolonial Belanda, hukum Islam dianggap sangat berbahaya dan berpotensi mengancam kekuasaan hegemonik mereka. Anggapan itu dapat dimengerti sebab, dalam banyak segi, pelaksanaan hukum Islam akan mengurangi pembelian produkproduk dan komoditas Barat, seperti mode pakaian, kosmetik, makanan, minuman keras, dan semacamnya. Pelaksanaan hukum Islam--jika sudah melibatkan komunitas Muslim--pasti membutuhkan campur tangan negara/pemerintah sehingga berpotensi mengembalikan kekuatan Islam sebagai satu entitas politik yang dipandang akan mengancam kepentingan eksploitatif dan hegemonik imperial Belanda itu.

Anderson pernah mengungkapkan bahwa terdapat perbedaan mendasar antara hukum Islam dan hukum Barat. Hukum Barat pada dasarnya bersifat sekuler sedangkan hukum Islam bersifat religius. Menurutnya, hukum Islam memiliki cakupan lebih luas dibandingkan dengan hukum Barat. Menurut para pemikir Barat, hukum--sebagaimana dipahami umum oleh para ahli hukum-adalah bahwa hukum yang berlaku, atau sekurang-kurangnya dinyatakan berlaku, merupakan beban-beban lembaga peradilan. Tidak terkecuali dengan hukum Islam. Apalagi, memang dimaklumi, bahwa hukum Islam memasukkan seluruh perbuatan individual maupun kolektivitas manusia ke dalam cakupan lembaga peradilan. Hukum Islam memang mencakup segala lapangan hukum--hukum publik, hukum privat, hukum nasional, dan hukum internasional-walaupun penjajah kolonial Barat menganggapnya sama sekali bukan hukum. ${ }^{15}$

Pengakuan pakar hukum Barat, seperti Anderson itu bahwa hukum Islam mencakup seluruh dimensi kehidupan manusia, menunjukan betapa persoalan hukum Islam sulit dipisahkan dari persoalan politik. Karenanya, pelaksanaan hukum Islam dalam wilayah publik--termasuk dalam pemerintahan dan hubungan

14 Ibid., hlm. 71-73.

${ }^{15}$ Anderson, JND, Islamic Law ini Modern world (Netherland: Van Hoeve, 1994), hlm.35. 
Taufiqurrahman

internasional--tentu merupakan pesoalan pilihan dan keputusan politik.

\section{Penutup}

Adanya kecenderungan penolakan atas penerapan syari'at Islam pada sebagian kalangan umat Muslim sesungguhnya merupakan gejala yang memprihatinkan. Setiap hukum yang nyatanyata menjadi keyakinan dan pegangan warganya akan berkembang dan dinamis jika diterapkan di tengah kehidupan masyarakat. Para ahli hukum Islam maupun para hakim pemutus perkara, akan terstimulasi untuk senantiasa "ber-ijtihâd" untuk memutus persoalanpersoalan baru yang muncul dalam berbagai bidang kehidupan masyarakatnya.

Kini, misalnya, para pakar hukum Islam, nyaris tidak mampu bersuara tentang soal-soal penting dan strategis di tengah-tengah masyarakat karena lingkup wilayah hukum Islam "hanya boleh beroperasi" pada segmen kehidupan privat. Itu pun hanya menyangkut bidang perkawinan, kewarisan, dan perwakafan, sedangkan segmentasi kehidupan dalam wilayah publik hukum Islam belum boleh menampakkan wajahnya. Misalnya, soal penanganan terorisme, pengaturan fasilitas-fasilitas mewah bagi para pejabat daerah hingga pusat, pembayaran beban utang luar negeri yang tidak manusiawi (cenderung mendlalimi), kenaikan harga-harga pokok kebutuhan masyarakat, penetapan gaji guru/dosen yang masih sangat rendah sejak profesi ini ada di negeri ini, penjualan (privatisasi) BUMN kepada pihak asing atau kolega bisnisnya, dan sebagainya.

Akibat ketidakmampuan para pakar hukum Islam dalam berijtihâd tentang persoalan-persoalan publik yang penting dan strategis, ditambah lagi dengan kurangnya keteladanan dalam penerapan syari'at Islam oleh para penyeru dan tokoh-tokoh Islam, serta adanya kampanye penghancuran syari'at Islam yang sangat gencar oleh pihak-pihak asing maupun nonasing, maka menjadi wajar jika terjadi apatisme terhadap hukum Islam semakin meningkat. Ironisnya, banyak orang yang justru mengaku dirinya muslim merasa senang, bahkan tidak menampakkan kerisauan apa pun dengan kondisi seperti itu. 


\section{Daftar Pustaka:}

Abdurrahman. Kompilasi Hukum Islam di Indonesia. Jakarta: Akademika Pressindo, 1992.

Ali, Daud. "Hukum Islam: Peradilan Agama dan Masalahnya". dalam Hukum Islam di Indonesia: Pemikiran dan Praktik, ed. Daud Ali. Jakarta: Rajawali Press 1994.

Alwi, Hasan. et al, Kamus Besar Bahasa Indonesia. Jakarta: Balai Pustaka, 2003.

Anderson, JND. Islamic Law ini Modern world. Netherland: Van Hoeve, 1994.

Anshari, Endang Saifuddin. Piagam Jakarta 22 Juni 1945. Bandung: Jenmar, 1997.

Hazairin, Demokrasi Pancasila. Bandung: Citra Aditya bakti, 1993. Ka'bah, Rifyal. Hukum Islam di Indonesia. Disertasi Universitas YARSI, Jakarta, 1999.

Husyari, Ahmad al-. al-Siyâsah al-Jazâiyah fî Fiqh al-'Uqûbah al-Islâmiyah al-Muqârin. Kairo: Maktabah al-Siyâsi, 1993.

Notonagoro. Pancasila Secara Ilmiah Populer. Bandung: Pustaka Amani, 1971.

Praja, Juhaya S. "Pengantar", dalam Hukum Islam di Indonesia: Pemikiran dan Praktik, ed. Daud Ali. Jakarta: Rajawali Press, 1994.

Tim Penyusun Ensiklopedi Hukum Islam. Ensiklopedi Hukum Islam. Jakarta: Intermasa, 1999.

Undang-Undang Dasar Negara Republik Indonesia Tahun 1945 Beserta Penjelasannya. Jakarta: Sekretariat Negara, 2003. 